\title{
EXCLUSIVE JURISDICTION FOR SMALL CLAIMS COURT: A STUDY PAPER AND RECOMMENDATIONS
}

\author{
GRANT DUNLOP AND JAMES CASEY*
}

\section{INTRODUCTION}

In 1978, Project Omega, acting on commission to the government of Alberta, conducted an investigation of the administration of the Small Claims Act. The resulting report' recognized the problems of confusion and inefficiency arising from the concurrent jurisdiction of the Provincial Court, Small Claims Division ${ }^{2}$ and the Court of Queen's Bench in actions below the Small Claims monetary limit. The report recommended that the possibility of exclusive jurisdiction for Small Claims Court be studied. Apparently no such study has been conducted.

Student Legal Services of Edmonton ${ }^{3}$ became concerned that the continuing system of concurrent jurisdiction was denying many poor persons access to the legal system and decided to study the problem in greater depth. This paper is the result.

\section{THE PRESENT SYSTEM}

In Alberta, a plaintiff suing for under two thousand dollars is given a choice of forums. He may sue in the Small Claims Court using its simplified procedure. ${ }^{4}$ Alternatively, he may sue in the Court of Queen's Bench using its more complicated procedure. In Queen's Bench if the action is for less than five hundred dollars, Queen's Bench small claims procedure can be used. ${ }^{5}$ In short, Small Claims Court and the Court of Queen's Bench have concurrent jurisdiction over claims under two thousand dollars.

An important difference between the two Courts is their default procedures. In Queen's Bench, if a defendant fails to file a statement of defence or a demand of notice the plaintiff automatically gets a judgment in his favour without having to appear in court or introduce any evidence as to the validity of his claim. ${ }^{6}$ In Small Claims Court the defendant need not file any documents; he can simply show up in Court on the date of the hearing and defend the action. If the defendant fails to appear then the plaintiff can get a default judgment once he has proven that the summons has been properly served on the defendant. ${ }^{7}$ To get a default judgment in Small Claims Court the plaintiff, his lawyer or his agent must appear in Court.

- Student Legal Services of Edmonton Legal Reform Project — January 1987.

1. Sue Corke, Project Omega: Small Claims Report, Volume A (1978).

2. Hereafter referred to as "Small Claims Court".

3. Student Legal Services of Edmonton is a non-profit organization of law students that provides legal information to the general public and legal assistance to those who can neither afford to hire a lawyer themselves nor obtain one through Legal Aid.

4. Provincial Court Act, R.S.A. 1980, c. P-20, ss. 35-73.

5. Alberta Rules of Court, 1969, rr. 659-682.

6. Alberta Rules of Court, 1969, r. 148.

7. Provincial Court Act, R.S.A. 1980, c. P-20, s. 54(1). 


\section{OBJECTIVES OF SMALL CLAIMS COURT}

The objectives of Small Claims Courts are many and varied but they can be gathered into three primary goals: simplicity, effectiveness and accessibility. ${ }^{8}$ The procedure in a Small Claims Court must be as simple and informal as possible to enable persons to represent themselves. Small claims generally cannot justify the cost of hiring a legal representative and the poor cannot afford to hire lawyers. In addition, a Small Claims Court must be effective in resolving legal disputes, doing so promptly, justly and according to the rule of law. Finally, a Small Claims Court must also be accessible to both plaintiffs and defendants. Accessibility requires a Small Claims Court to be well known, geographically close to potential litigants and inexpensive to use.

Many academic and empirical studies have considered whether Small Claims Courts are meeting these objectives. ${ }^{9}$ However, almost without exception, this research has evaluated the legal system from the plaintiff's perspective. As pointed out by His Honour, Judge Spevakow of the Provincial Court of Alberta, the defendant has been all but ignored by the system and its observers: ${ }^{10}$

In the quest to obtain a workable system to assist the individual before the Court as a
litigant, it has been assumed that the individual would be coming in as a plaintiff. The
objective has been to make it more attractive to allow the plaintiff into Court. It was not
realized that the individual, more often than not, appears as a defendant. The obvious
defect, as stated earlier in this article, is that the trappings intended to serve the lay person
as plaintiff will victimize him as defendant.
Alberta is not alone: the procedure is plaintiff-oriented. The plaintiff is given informa-
tion and assistance from the staff if he desires it. He is advised as to procedure and is given
assistance relating to the conduct of his case at the trial. When field studies are conducted
and points are examined to make the system more workable, it is with the purpose of
making the Court system more available to the plaintiff, not to the lay person who
appears as defendant.

But the defendant must not be forgotten. He, too, deserves a simple, effective and accessible forum where he can tell his side of the story and be protected from possibly invalid claims. While the small claims system may be simple and effective, it is the contention of this paper that for many defendants to Small Claims actions, it is inaccessible.

\section{ARGUMENTS AGAINST CONCURRENT JURISDICTION}

A hypothetical situation will best demonstrate how concurrent jurisdiction acts to deny the poor access to the legal system.

Jack, an Edmonton resident, has recently lost his job and so has moved out of the duplex he was renting into a smaller, cheaper apartment. His former landlord feels Jack did not give adequate notice when he moved out and thinks Jack consequently owes him one month's rent, five hundred and fifty dollars. The landlord's lawyer has initiated an action in the Court

8. Manitoba Law Reform Commission, Report on the Structure of the Courts; Part II: The Adjudication of Smaller Claims (1983) 5-6.

9. E.g. Ontario Law Reform Commission, Report on Administration of Ontario Courts, Part III (1973); P. Sigurdson, Small Claims Courts and Consumer Access 1o Justice (1976); C. Axworthy. "Controlling the Abuse of Small Claims Courts" (1976), 22 McGill L.J. 480.

10. R.B. Spevakow, "Small Claims for Alberta: Some Recommendations" (1979) 17 Alta. L. Rev. 244 at 248. 
of Queen's Bench and Jack has been served with a statement of claim. Jack feels he does not owe his former landlord anything as he told the landlord's wife that he was moving out a month and a half in advance.

Jack telephones the Clerk of the Court of Queen's Bench to find out what to do and is given some cursory information on pleadings, statements of defence and discoveries. Jack learns that in theory he can represent himself. However he doesn't understand how to fill out the forms, much less how to behave in Court. He is intimidated by the Court building itself and all the people bustling about in it. He realizes that the Court of Queen's Bench is not designed for the unrepresented.

Jack needs a lawyer to fight this suit for him. However a few telephone calls reveal tht Jack cannot afford a lawyer's retainer. Next Jack approaches Legal Aid but they turn him down because it is not cost effective to appoint a lawyer when the lawsuit is only for $\$ 550.00$. Legal Aid refers Jack to Student Legal Services. The students inform Jack that they cannot help him either because they have no standing to appear in the Court of Queen's Bench."

Jack has only one option left. He ignores the Statement of Claim and in due time judgment is entered against him without his side of the case being heard. Small Claims Court is designed to allow Jack to present his own defence but since the landlord chose to sue in Queen's Bench, Jack has been denied access to Small Claims Court.

Why did the landlord choose to sue Jack in Queen's Bench rather than Small Claims Court? After all, one of the reasons Small Claims Courts were originally created was to allow plaintiffs an inexpensive means of recovering their small claims. In this hypothetical situation the landlord chose to sue in the Court of Queen's Bench simply to make it more difficult for Jack to raise a defence. The landlord knew that Jack could not afford a lawyer and was unlikely to defend the action by himself. The choice of the Queen's Bench forum avoided the possibility of Jack raising a valid defence and enabled the landlord to obtain a quick, cheap default judgment since the landlord's lawyer was not required to appear in Court.

Even if Jack could afford to hire a lawyer, the lawyer's fee would be greater than the five hundred and fifty dollars the landlord is claiming. Hence it is cheaper to surrender than to fight and win! Since Jack would lose money by defending his claim in Court, he would have to be doing so "on principle". Only the wealthy can afford such a luxury while empirical studies have shown that it is usually people of lower incomes who find themselves in Jack's situation. ${ }^{12}$

\section{EXTENT OF THE PROBLEM}

One of the few studies which considers the extent to which plaintiffs are suing in Queen's Bench for claims under the Small Claims limit is The Operation of the Unsecured Creditors' Remedies System in Alberta. ${ }^{13}$ It

11. Alberta Rules of Court, 1969, r. 673; Legal Profession Act, R.S.A. 1980, c. L-9, s. 93.

12. Institute of Law Research and Reform, Remedies of Unsecured Creditors (1986) 154.

13. Institute of Law Research and Reform, The Operation of the Unsecured Creditors' Remedies System in Alberta (1986) 25. 
examined a sample of judgments filed in the offices of the Clerks of the Court of Queen's Bench in Alberta in 1980 and 1981. ${ }^{14}$ At that time the Small Claims monetary limit was one thousand dollars. The study discovered that of the judgments filed in the Court of Queen's Bench below one thousand and four dollars (the monetary limit plus four dollars Court costs), 35.1 per cent of the plaintiffs had sued in Queen's Bench rather than Small Claims Court. The study points out that some of these plaintiffs would be administrative tribunals which are required to sue in Queen's Bench so the percentage of plaintiffs choosing Queen's Bench would be somewhat lower.

Unfortunately, the study does not reveal how many of the judgments from suits initiated in Queen's Bench rather than Small Claims Court were default judgments. Studies show that default debtors have below average incomes. ${ }^{15}$ We predict that defendants being pursued for amounts below the small claims limit also have lower than average incomes and could not afford to hire a lawyer to defend a Queen's Bench action. Therefore it is reasonable to conclude that a substantial number of these suits are defaulted.

The data suggests that the practice of choosing the Queen's Bench forum is wide-spread in Alberta. It is impossible to accurately ascertain the motivations behind such a choice without interviewing each of the plaintiffs involved in the study. As suggested above, some plaintiffs may choose Queen's Bench in order to preclude a defence. Others may choose the higher Court because of its faster default procedure or because they feel more at ease in Queen's Bench surroundings. Some lawyers have suggested to us that they feel Small Claims Court is "stacked" in favour of the defendant so they choose Queen's Bench. Whatever the reason for the choice, plaintiffs are obtaining default judgments against defendants, some of whom could have raised a valid defence in Small Claims Court. ${ }^{16}$ This is the argument against concurrent jurisdiction.

\section{ARGUMENTS IN FAVOUR OF CONCURRENT JURISDICTION}

\section{A. DEFAULT JUDGMENTS}

It may be argued that concurrent jurisdiction should be retained because the Queen's Bench option of a quick default judgment without a Court appearance saves both time and money. Many actions are uncontested debts and obtaining a judgment is simply the first step in using the unsecured creditors' remedies system. In such a situation, why should a plaintiff not be able to obtain a default judgment "over the counter"?

14. The study examined a randomly selected group of 2316 non-matrimonial money judgments filed in three Alberta judicial districts. These judgments include actions initiated in the Court of Queen's Bench as well as actions initiated in Small Claims Court and filed in the Court of Queen's Bench pursuant to the Provincial Court Act, R.S.A. 1980, c. P-20, s. 57(3).

15. Institute of Law Research and Reform, supra $\mathrm{n} .12$ at 154.

16. The paucity of empirical research in this area makes quantitative conclusions difficult. An empirical study including interviews of plaintiffs and defendants is required in order to authoritatively determine the motivations behind choosing Queen's Bench, the percentage of actions which are defaulted, and the percentage of defendants who would have defended if the action had been brought in Small Claims Court. Unfortunately, such a study is beyond the scope of this paper. It is hoped that our paper will spur further research in this area. Until such a time, our conclusions out of necessity must be non-quantified. 
It is conceded that many debts are undisputed and law suits resulting from such debts would be undefended whether initiated in the Court of Queen's Bench or in Small Claims Court. However, in many other cases the defendant would have presented a defence if he had been sued in Small Claims Court. If the unavailability of default judgments without Court appearances is a concern then the solution may be to allow "over the counter" default judgments in Small Claims Court while abolishing concurrent jurisdiction. An Intention to Defend Form written in plain language explaining the default procedure could be attached to the small claims summons. The defendant would be required to sign the form and return it to the clerk's office by a certain date if he intended to defend the action. If the defendant failed to do so then the plaintiff would obtain a default judgment without appearing in Court provided he had filed an affidavit swearing that the defendant had been properly served.

There are two arguments against permitting default judgments in Small Claims Court. First, some commentators argue that plaintiffs should be required to establish a prima facie case before obtaining a default judgment. ${ }^{17}$ However, if a defendant wishes to dispute a claim against him, he must be willing to appear in Court and explain his side of the story. Second, the requirement that the defendant return an Intention to Defend Form complicates small claims procedure somewhat. However, signing and returning a simple form which clearly explains the consequences of failing to notify the clerk of an intention to defend is a small burden for a defendant with a valid defence.

\section{B. LEGAL COSTS}

Some lawyers argue that since legal costs of only five dollars can be awarded in Small Claims Court, ${ }^{18}$ the Queen's Bench option should remain available to allow those plaintiffs who employ lawyers to recover a greater portion of their expenses.

However, actual legal costs are much lower in Small Claims Court because of the simpler procedure. Hence, even when Court awarded costs are considered, most trials would be less expensive to run in Small Claims Court than in the Court of Queen's Bench.

\section{COMPLEX CASES}

It may be argued that dual jurisdiction should be retained since Queen's Bench procedure may be more appropriate than Small Claims procedure in certain exceptional cases. Discoveries may be required or the parties may wish to obtain a decision at the Queen's Bench level on an important point of law.

A system with exclusive jurisdiction in Small Claims Court could allow for exceptions. There could be a right to transfer an action to the Court of Queen's Bench if all parties consented. In addition each party could have the right to apply to Small Claims Court to have the matter transferred.

17. Spevakow, supra n. 10 at 250.

18. The Small Claims Division of Provincial Court, Tariff of Fees Regulation, Alta. Reg. 145/ 80. 
The Court could then decide on the party's or its own motion whether the Court of Queen's Bench would be a more appropriate forum.

\section{CONSTITUTIONAL ARGUMENT}

The constitutionality of provincial creation of Small Claims Court is well established. ${ }^{19}$ As well, it is clear that a province can remove jurisdiction from a superior Court and give it to an administrative tribunal such as a Worker's Compensation Board ${ }^{20}$ or the Immigration Appeal Board. ${ }^{21}$ It is less clear whether the province can constitutionally remove the jurisdiction of the Court of Queen's Bench, a superior Court, to hear claims under two thousand dollars and bestow it exclusively upon Small Claims Court.

The Supreme Court of Canada in McEvoy v. The Attorney General of New Brunswick ${ }^{22}$ considered the constitutionality of a proposal to create a unified criminal court in New Brunswick. The issue, as seen by the Court, was: ${ }^{23}$

$$
\begin{aligned}
& \text { governether s. } 96 \text { of the Constitution Act, } 1867 \text { is a bar to a plan whereby the federal } \\
& \text { jurisdiction of Provincial Superior Courts to a new Court to be called the "unified } \\
& \text { criminal Court" the judges of which would be provincially appointed. }
\end{aligned}
$$

The Court concluded that the proposal was unconstitutional since its effect would be to deprive the Governor General of his power under s. 96 to appoint the judges who try indictable offences. ${ }^{24}$

However, the Supreme Court was particularly concerned that the proposal would remove all the criminal jurisdiction of the New Brunswick Superior Court: ${ }^{2 s}$

What is being contemplated here is not one or a few transfers of criminal law power, such as has already been accomplished under the Criminal Code, but a complete obliteration of Superior Court criminal law jurisdiction.

Later in the judgment the Court goes on to observe that "There is, in our view, a cardinal difference between mere alteration or diminution of criminal jurisdiction and complete exclusion of such jurisdiction." ${ }^{26}$

What this paper proposes, of course, is not a "complete obliteration" of Superior Court civil law jurisdiction but rather only the removal of jurisdiction over civil actions for debt or damages under two thousand dollars from the Court of Queen's Bench. This is a "mere diminution" rather than a "complete exclusion" of civil jurisdiction. Following this distinction as set out by the Supreme Court in McEvoy it is submitted that establishing exclusive jurisdiction for Small Claims Court would not be contrary to s. 96 of the Constitution Act, 1867.

19. F. Nielsen \& Son Limited v. Marchant (1967) 61 W.W.R. 212 (Alta. D.C.); and class cited therein.

20. Farrell v. Workmen's Compensation Board [1962] S.C.R. 5; Dominion Canners v. Costanza [1923] S.C.R. 46.

21. Re Immigration Act; Re Edery (1969) 70 W.W.R. 553 (B.C.S.C.).

22. [1983] I S.C.R. 704 .

23. Id. at 707.

24. Id. at 720 .

25. Id. at 719.

26. Id. at 722 . 


\section{OTHER STUDIES CONSIDERING CONCURRENT JURISDICTION}

Other studies which have examined the problem of concurrent jurisdiction have generally recommended that there be exclusive jurisdiction for Small Claims Court.

The Manitoba Law Reform Commission ${ }^{27}$ recommended that the Provincial Judges Court (Civil Division) be given exclusive jurisdiction over all Claims under $\$ 3,000$ with the provision that the Court be given the authority to transfer an action to the Court of Queen's Bench in the following cases: ${ }^{28}$

1. where there is the consent of all of the parties to the action, in which case the transfer shall be ordered;

2. where the defendant pleads a set-off or counter-claim and the Court is satisfied that the set-off or counter-claim involves a matter beyond the jurisdiction of the Court; or

3. where the Court is satisfied that, having regard to the exceptional circumstances of the case, it would be proper to do so.

Christopher Axworthy, in Controlling the Abuse of Small Claims Courts ${ }^{29}$ recommended that Small Claims Courts be granted exclusive jurisdiction in order to prevent plaintiffs from obtaining default judgments at the superior Court level.

A report prepared for the Consumer Research Council of Canada advocated exclusive jurisdiction for Small Claims Courts in order to clear superior Court dockets and to force creditors to use simpler procedures. The report also recommended that Small Claims Courts be given the power to transfer cases to a superior Court where the issues are complicated or will have wide-ranging effects. As an alternative, the report recommends that if concurrent jurisdiction were to continue then an individual defendant should have the authority to transfer the matter down to Small Claims if the case has been initiated in the superior Courts. ${ }^{30}$

On the other hand, a study prepared for the Nova Scotia Law Reform Advisory Commission, while recognizing that forum shopping should be discouraged, followed a National Institute for Consumer Justice study in claiming that "legislators, judges and probably the public at large will be less willing to allow a great deal of informality and experimentation in the Small Claims Court if they are the only place a claimant can initiate a claim. ${ }^{31}$

The objection to the informality of Small Claims Court should be satisfied by the option of the Court to transfer the action up to a higher Court where such a Court would be the more appropriate forum. The objection to experimentation is difficult to understand since experiments, almost by definition are small scale and of limited scope, unlikely to cause anyone difficulty.

27. Supra n. 8 at 23.

28. Id.

29. Supra n. 9 at 493.

30. Sigurdson, supra n. 9 at $\mathbf{3 0}$.

31. Small Claims - A Study Paper (1974) 48. 


\section{RECOMMENDATIONS}

Concurrent jurisdiction denies many poor defendants access to the legal system. Exclusive jurisdiction would improve the poor's access to Small Claims Court. We find this argument in favour of exclusive jurisdiction to be more persuasive than those against.

We therefore make the following recommendations:

1. That, subject to the exceptions in recommendation 2., the Provincial Court, Small Claims Division be given exclusive jurisdiction over actions under the Small Claims limit, currently two thousand dollars.

2. That the Provincial Court, Small Claims Division be given authority to transfer an action up to the Court of Queen's Bench on the application of one of the parties to the action or on the Court's own motion:

(a) where all parties to the action consent to the transfer in which case the transfer must be ordered;

(b) where the Court is satisfied that due to the exceptional circumstances of the case it should be litigated in the Court of Queen's Bench; and

(c) where it appears that a claim, counterclaim or defence involves a matter that is beyond the jurisdiction of the Court. ${ }^{32}$

3. That the Provincial Court, Small Claims Division establish the following default judgment procedure. An Intention to Defend Form would accompany the Small Claims summons served on the Defendant. The defendant would be required to sign the form and return it to the clerk's office by a certain date if he intended to defend the action. If the defendant failed to do so then the plaintiff would obtain a default judgment without appearing in Court provided he had filed an affidavit swearing that the defendant had been properly served.

It is submitted that exclusive jurisdiction for Small Claims Court, coupled with a default judgment procedure, would best balance the interests of both plaintiffs and defendants.

32. This provision currently exists: Provincial Court Act, R.S.A. 1980, c. P-20, s. 67. 